\title{
Effects of Fruit and Pollen Exudates on Growth of Botrytis cinerea and Infection of Plum and Nectarine Fruit
}

\author{
J. F. Fourie and G. Holz, Department of Plant Pathology, University of Stellenbosch, Private Bag X1, Matieland \\ 7602 , South Africa
}

\begin{abstract}
Fourie, J. F., and Holz, G. 1998. Effects of fruit and pollen exudates on growth of Botrytis cine$r e a$ and infection of plum and nectarine fruit. Plant Dis. 82:165-170.

Sugars in exudates from Harry Pickstone plum and Sunlite nectarine fruit and from pollen of weeds commonly found in orchards were determined by gas-liquid chromatography, and their effect on the development of Botrytis cinerea was determined in vitro and in vivo. Fructose, glucose, and sorbitol were the only sugars detected in exudates of immature fruit. They occurred at low concentrations, but their concentration generally increased as fruit ripened. Sucrose was first detected during maturation. In nectarine, an increase in sugar concentration, especially sucrose, was pronounced during the period of rapid cell enlargement, which occurred approximately 2 weeks before harvest. Absorbance readings of culture media amended with sugar indicated that the hexose sugars (fructose and glucose) and sucrose did not markedly influence growth of $B$. cinerea at concentrations below 0.22 and $0.12 \mathrm{mM}$, respectively. The hexose sugars caused a steady increase in growth when supplied at concentrations in excess of $0.44 \mathrm{mM}$, and sucrose caused a steady increase in growth at $0.23 \mathrm{mM}$. The stimulatory effect of fruit exudates on growth of $B$. cinerea on glass slides coincided with the period of rapid sugar release from the fruit and the shift in susceptibility to decay. Only fructose $(1.72 \mathrm{mM})$ and glucose $(0.72$ $\mathrm{mM}$ ) were detected in nectarine pollen exudates. Pollen exudates from weeds stimulated fungal growth and significantly increased the aggressiveness of the pathogen on plum and nectarine fruit when added to conidia during the last 4 weeks prior to the picking-ripe stage. The study showed that changes in the composition of nectarine and plum fruit exudates may contribute to the late-season susceptibility of these fruit to $B$. cinerea infection.
\end{abstract}

Botrytis cinerea Pers.:Fr. is one of the major pathogens responsible for postharvest decay of stone fruit in the Western Cape Province of South Africa (12). The disease commonly occurs on plum blossoms in local stone fruit orchards (25) and plays an important part in blossom blight (15). The fungus does not enter plum and nectarine fruit via flower parts to establish latent infections (15). Unwounded fruit are resistant to the pathogen during the early developmental stages $(14,16)$. It is not until the early (nectarine) or last phase (plum) of rapid cell enlargement that disease development occurs $(14,16)$. Injuries usually play an important role in late-season susceptibility, especially for plum fruit $(13,14)$.

Nutrients influence germination and growth $(1,5,6)$ and infection processes in B. cinerea $(10,18,26)$. Edlich et al. (10) suggested that stimulation of infection by $B$. cinerea after addition of certain sugars

Corresponding author: G. Holz

E-mail: gh@maties.sun.ac.za

Current address of J. F. Fourie: Unifruco, P.O. Box 1231, Stellenbosch 7600, South Africa

Accepted for publication 19 September 1997.

Publication no. D-1997-1126-01R

(C) 1998 The American Phytopathological Society to artificial inoculum is probably due to the active forms of oxygen formed rather than to a nutritional effect. Sugars act as substrates for the production of hydrogen peroxide and other forms of superoxide and hydroxyl radicals, which are highly toxic and capable of destroying relatively inert materials, such as cutin.

A wide range of organic and inorganic substances that promote the saprophytic and parasitic growth of $B$. cinerea are leached from living plant tissue $(1,4,21)$ or diffused into water droplets lying on the tissues (26). This study was undertaken to investigate changes in the sugar composition of nectarine and plum fruit exudates during fruit development and to examine the effect of these exudates and those of pollen from weeds commonly found in orchards on the growth of $B$. cinerea and the infection process.

\section{MATERIALS AND METHODS}

Inoculum. A culture of $B$. cinerea isolated from naturally infected plum fruit was maintained in a lyophilized state. Inoculum was prepared by culturing the fungus on potato dextrose agar (PDA) in petri dishes for 10 days at $22^{\circ} \mathrm{C}$ under a diurnal regime (12-h photoperiod). Spores were collected by inverting the sporulating culture over a petri dish containing sterile distilled water and by gently tapping the bottom of the inverted half. This harvesting method avoided contamination of spores by nutrients from the medium. Spore counts were made with a hemacytometer, and suspensions were adjusted to approximately $1 \times 10^{5}$ spores per ml. Germination of conidia on water agar was examined at each inoculation to verify their viability; (viability was $\geq 90 \%$ ).

Preparation of leachates. Sound, unblemished fruit were collected from fungicide-free Harry Pickstone plum and Sunlite nectarine trees. For each cultivar, 30 fruit with attached stems were collected at biweekly intervals commencing at the hard, green, unripe stage until the picking-ripe stage. At each sampling, fruit were packed unwashed onto sterile epoxy-coated steelmesh screens. Two 0.05-ml drops of sterile glass-distilled water were pipetted onto the surface of each fruit. Screens supporting fruit were carefully placed into ethanolsterilized Plexiglas moist chambers $(60 \times$ $30 \times 60 \mathrm{~cm}$ ) and kept at $20^{\circ} \mathrm{C}$ and a high relative humidity $(\geq 93 \%)$ under a diurnal regime (12 h of white fluorescent light and $12 \mathrm{~h}$ of dark). After $15 \mathrm{~h}$, the droplets were collected with sterile micropipettes, and those from each fruit type were pooled. Pooled samples were sterilized by passage through a sterile membrane filter $(0.22 \mu \mathrm{m}$; Millipore Corp., Bedford, MA), freezedried, and stored under vacuum.

Flowers of the two stone fruit cultivars and two weeds, wild radish (Raphanus raphanistrum L.) and yellow sorrel (Oxalis pes-caprae L.), commonly growing in and near stone-fruit orchards, were collected at the budding stage. The stamens were removed under a stereo microscope, and the anthers were separated from the filaments. Pollen leachates were prepared by suspending 40 anthers per milliliter of distilled water. The suspension was agitated vigorously for $1 \mathrm{~min}$ in a Vortex mixer, filter-sterilized by passing it through a Millipore membrane, $0.22-\mu \mathrm{m}$ pore size, freeze-dried, and stored under vacuum.

Analysis of sugars in fruit and pollen exudates. Individual and total sugars in sterile leachates were determined with gasliquid chromatography analysis according to the method of Fourie and Basson (17). A $500-\mu l$ aliquot of each sample was pipetted into vials, and $500 \mu \mathrm{l}$ of absolute ethanol was added. A standard sugar solution containing D-glucose $(180 \pm 0.01 \mathrm{mg}), \mathrm{D}-$ fructose $(180 \pm 0.01 \mathrm{mg})$, sucrose $(342 \pm$ $0.01 \mathrm{mg})$, and sorbitol $(182 \pm 0.01 \mathrm{mg})$, dissolved in $20 \mathrm{ml}$ of distilled water and 
diluted to $100 \mathrm{ml}$ with ethanol, was also prepared. Aliquots of $200 \mu \mathrm{l}$ of the standard sugar solution and sample extract were evaporated to dryness over calcium chloride under reduced pressure at room temperature $\left(22 \pm 2^{\circ} \mathrm{C}\right)$ in septum-sealed vials. The internal standard solution $(220$ $\mu \mathrm{l} / 256.0 \mathrm{mg}$ of triphenylethylene $/ 100 \mathrm{ml}$ of pyridine) was added to dissolve the dried material by agitating it in an ultrasonic bath at $20^{\circ} \mathrm{C}$ for $15 \mathrm{~min}$. After agitation, hexamethyldisilazane $(200 \mu \mathrm{l})$, followed by trifluoroacetic acid $(25 \mu \mathrm{l})$, was added. Vials were capped and ultrasonically treated to obtain a homogeneous, clear solution. Aliquots (approximately $1.5 \mu \mathrm{l}$ ) were injected with an automatic system into a Hewlett-Packard 5831 gas chromatograph equipped with a flame ionization detector and an electronic integrator. The first $1.2 \mathrm{~m}$ of a glass column $(3 \mathrm{~m} \times 2 \mathrm{~mm}$ [internal diameter]) was packed with $1.5 \%$

Table 1. Sugars detected by gas-liquid chromatography in exudates ${ }^{z}$ of Harry Pickstone plum and Sunlite nectarine fruit during different developmental stages

\begin{tabular}{cllll}
\hline \multirow{2}{*}{$\begin{array}{l}\text { Weeks before } \\
\text { harvest }\end{array}$} & \multicolumn{3}{c}{ Sugar concentration $(\mathbf{m M})$} \\
\cline { 2 - 4 } Plum & Fructose & Glucose & Sorbitol & Sucrose \\
11 & 0 & 0.0043 & 0.0011 & 0 \\
9 & 0.0054 & 0.0061 & 0.0094 & 0 \\
7 & 0.0057 & 0.0128 & 0.0069 & 0 \\
5 & 0.0214 & 0.0381 & 0.0082 & 0 \\
3 & 0.0215 & 0.0484 & 0.0157 & 0 \\
2 & 0.0103 & 0.0485 & 0.0045 & 0.0429 \\
1 & 0.0122 & 0.0376 & 0.0164 & 0.0577 \\
0 & 0.036 & 0.0544 & 0.0131 & 0.0599 \\
Nectarine & & & & \\
7 & 0.0024 & 0.0014 & 0.0072 & 0 \\
4 & 0.0159 & 0.0242 & 0.0092 & 0 \\
2 & 0.0093 & 0.0132 & 0.0145 & 0 \\
1 & 2.3964 & 1.9223 & 1.0938 & 2.3831 \\
0 & 1.3502 & 1.2809 & 1.6322 & 3.4143 \\
\hline
\end{tabular}

${ }^{\mathrm{z}}$ Exudates were collected from detached, unwashed fruit kept for $15 \mathrm{~h}$ at $20^{\circ} \mathrm{C}$ in moist chambers.
$\mathrm{OV}-1$ and the last $1.8 \mathrm{~m}$ with $2 \% \mathrm{OV}-225$. Chromosorb W, 60 to 80 mesh, was used as carrier material. Nitrogen carrier gas flow rate was at $15 \mathrm{ml} / \mathrm{min}$. The supply of hydrogen and air to the detector was set at 42.5 and $255 \mu \mathrm{l} / \mathrm{min}$, respectively. The initial oven temperature was $155^{\circ} \mathrm{C}$. After $1.5 \mathrm{~min}$, it was elevated by $5^{\circ} \mathrm{C} / \mathrm{min}$ for 5 min, after which the oven temperature was elevated by $10^{\circ} \mathrm{C} / \mathrm{min}$ until $225^{\circ} \mathrm{C}$ was reached. Detector temperature was $300^{\circ} \mathrm{C}$, and the temperature of the injection block was $250^{\circ} \mathrm{C}$. An equilibrium time of $2 \mathrm{~min}$ at the initial temperature was allowed for equilibrium before injection of each sample. Quantification was done with an electronic integrator relative to the area of the internal standard.

Growth of $B$. cinerea in media amended with sugars. $B$. cinerea was grown in 25-ml Erlenmeyer flasks in a basic salts solution amended with sugar at concentrations corresponding to those found in exudates of developing plum and nectarine fruit. The salts solution contained $2 \mathrm{~g}$ of $\mathrm{K}_{2} \mathrm{HPO}_{4}, 1 \mathrm{~g}$ of $\mathrm{MgSO}_{4} \cdot 7 \mathrm{H}_{2} \mathrm{O}, 1 \mathrm{~g}$ of $\mathrm{KCl}, 0.02 \mathrm{~g}$ of $\mathrm{FeSO}_{4} \cdot 7 \mathrm{H}_{2} \mathrm{O}$, and $2 \mathrm{~g}$ of asparagine in 1 liter of distilled water. The medium was autoclaved $(5 \mathrm{ml}$ per flask for $15 \mathrm{~min}$ at $121^{\circ} \mathrm{C}$ ) separately from the sugar solutions to avoid any reaction between the individual sugars and nutrients in the basic salts solution. Five $\mathrm{ml}$ of sugar solution,
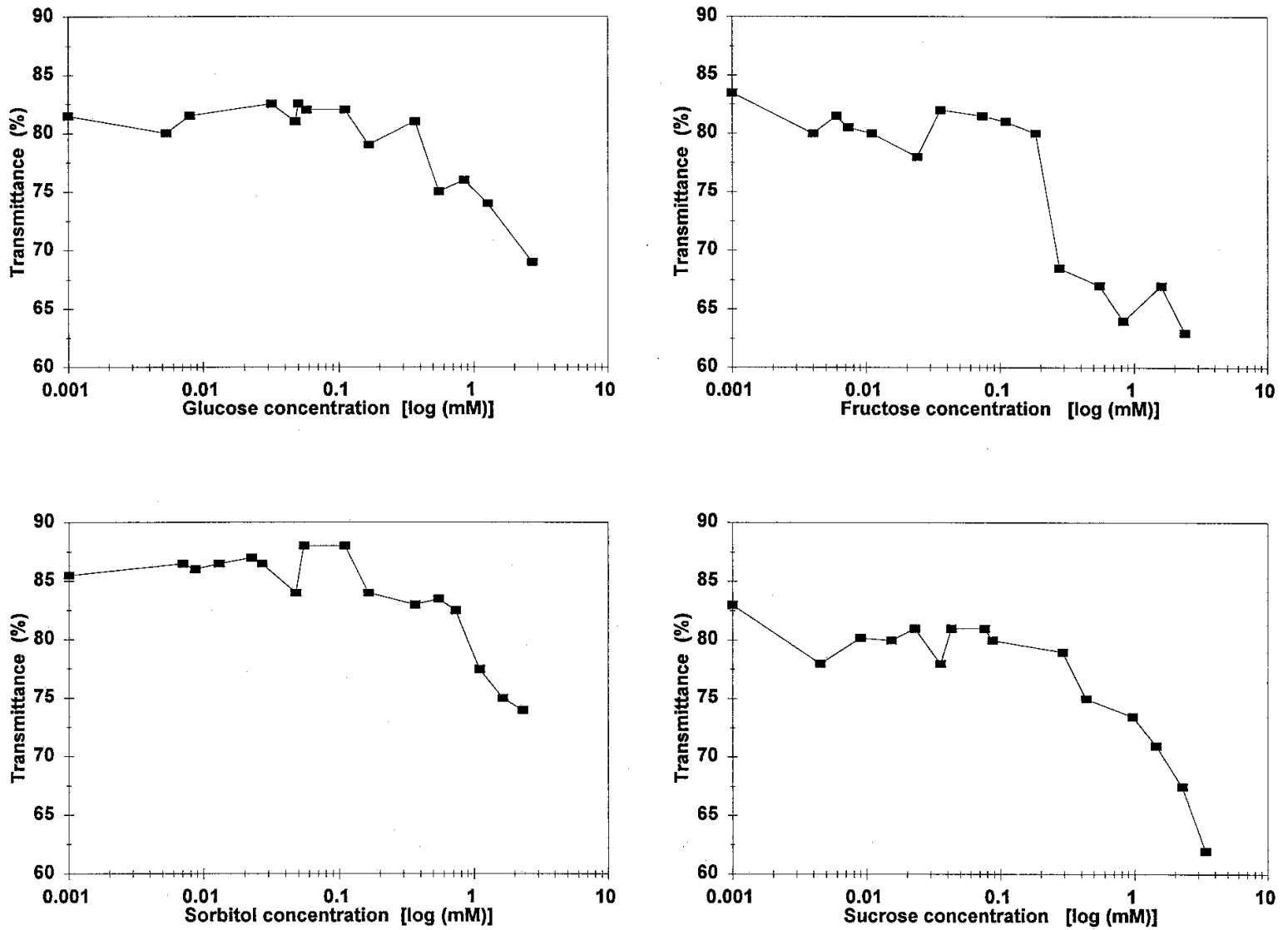

Fig. 1. Percent transmittance at $620 \mathrm{~nm}$ of culture media of Botrytis cinerea after 7 days growth at $23^{\circ} \mathrm{C}$ in a basic salts medium amended with sugar at concentrations found in fruit exudates. Sugar concentrations used were nonlinear; transmittance was therefore plotted against the log 10 transformation values. 
obtained from stock solutions of fructose, glucose, sucrose, and sorbitol, and sterilized by filtering through a $0.22-\mu \mathrm{m}$ Millipore membrane, was then added to the sterile salts solution. Control treatments received $5 \mathrm{ml}$ of sterile distilled water. The $B$. cinerea spore suspension was filtered through a $0.22-\mu \mathrm{m}$ Millipore membrane; the retrieved spores were rinsed with sterile distilled water while still under vacuum and then rinsed from the membrane using an atomizer with sterile water and compressed air. The suspension was adjusted with sterile distilled water to contain $3 \times$ $10^{5}$ spores per $\mathrm{ml}$, and $0.1 \mathrm{ml}$ was added with sterile pipettes to each flask. The flasks were incubated at $23^{\circ} \mathrm{C}$ on a shaking machine at $120 \mathrm{rpm}$. Growth of B. cinerea in the different solutions was measured after 7 days by recording the absorbance of culture media (11) at $620 \mathrm{~nm}$ with the aid of a Beckman DU 65 spectrophotometer with a $1-\mathrm{cm}$ path length.

The rate of utilization of the simple sugars by $B$. cinerea in the different solutions was also determined. Samples of $1 \mathrm{ml}$ were taken from the growth cultures $0,3,24,48$, 72 , and $120 \mathrm{~h}$ after inoculation. The samples were passed through a $0.22-\mu \mathrm{m}$ Millipore membrane to remove fungal growth. A $500-\mu l$ aliquot of each sample was pipetted into vials, and $500 \mu \mathrm{l}$ of absolute ethanol was added. The samples were dried under vacuum at $20^{\circ} \mathrm{C}$, and the sugars were quantified by gas-liquid chromatography as previously described.
Effect of exudates from fruit and pollen on conidium development. The effect of pollen and fruit exudates on germination was determined by the raised-slide technique (11). Two pieces $(20 \times 15 \times 2 \mathrm{~mm})$ of glass were cut from used microscope slides and placed $50 \mathrm{~mm}$ apart on each end of a glass slide to support a coverslip 76 $\mathrm{mm}$ in length. Pollen and fruit exudates were prepared as described previously. A 25- $\mu$ l drop of spore suspension was placed on a glass slide, and a $25-\mu 1$ drop of pollen or fruit exudate was added. In control treatments, droplets of sterile distilled water were added to the spore suspension. A coverslip was laid across the glass pieces and depressed gently to trap the test solution between the slide and coverslip. After incubation, the glass supports were removed to allow the coverslip to drop onto the slide. In this process, the spore suspension spread uniformly over the slide. Percent germination and germ tube growth were assessed after $8 \mathrm{~h}$ of incubation at $21^{\circ} \mathrm{C}$. Germination assessments were based on a count of 10 replicate sets of 100 randomly selected conidia. Germ tube lengths (10 replicate sets of 10 germ tubes on each slide) were measured with the aid of an eyepiece graticule. The experiment was repeated three times. Data were subjected to analysis of variance, and treatment means were separated by the $t$ test (growth in fruit exudates) or Duncan's multiple range test (growth in pollen exudates) at $P$ $=0.05$.
Effect of pollen exudate on fruit infection. The effect of yellow sorrel pollen exudate on the infection of stone fruit was determined at different stages of fruit development. Harry Pickstone plum and Sunlite nectarine fruits (five replicate samples of 20 fruits of each cultivar) were collected at biweekly intervals commencing at the hard, green, and unripe stage until the picking-ripe stage. The fruit was surface-disinfested with $70 \%$ ethanol and allowed to dry before being packed onto sterile epoxy-coated steel mesh screens. A circle $1 \mathrm{~cm}$ in diameter was drawn on the surface of the fruit to indicate the inoculation site. A 25- $\mu$ l drop of spore suspension was placed inside the marked area, and a $25-\mu \mathrm{l}$ drop of filter-sterilized pollen exudate was added. In control treatments, droplets of sterile distilled water were added to the spore suspension. Screens carrying fruit were carefully placed into ethanol-sterilized moist chambers and incubated as previously described. Percent fruit showing decay at the inoculation site was recorded after 2 weeks. Two-way analysis of variance (ANOVA) was used to determine the effect of inoculation period and conidial suspension on decay. Means were compared for significance using Student's $t$ LSD test at $P=0.05$.

\section{RESULTS}

Sugars in fruit and pollen exudates. Fructose, glucose, and sorbitol were the only sugars detected in exudates of imma-
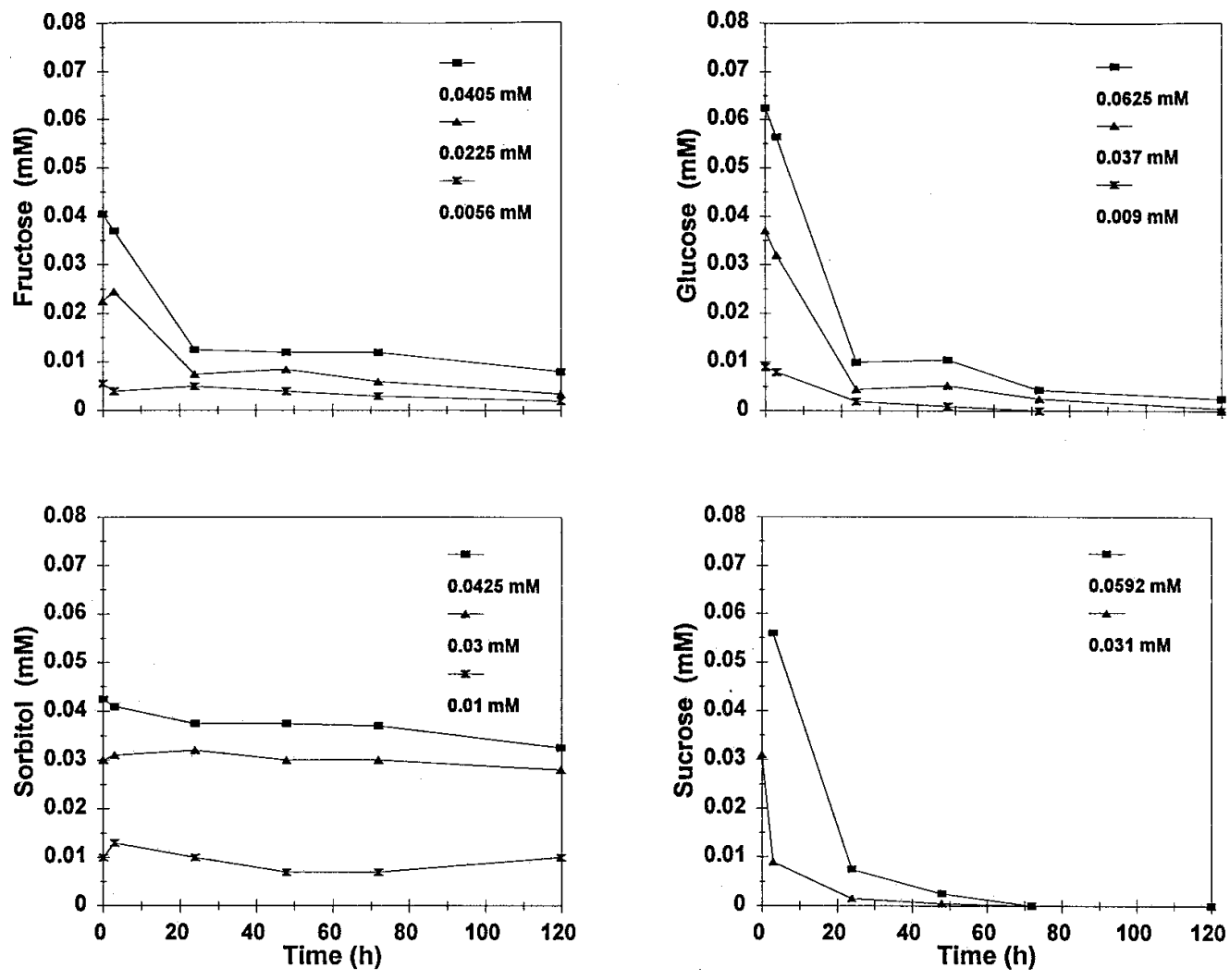

Fig. 2. Uptake of different sugars by Botrytis cinerea from a basic salts medium amended with sugar at levels (Table 1) corresponding to concentrations found in exudates of immature plum and nectarine fruit. 
ture plum and nectarine fruit (Table 1). Sucrose was first detected during maturation, which occurred approximately 2 weeks before harvest. The sugars were exuded at low quantities by immature fruit, but their concentrations generally increased as the fruit ripened. In nectarine, an increase in sugar concentration, especially that of sucrose, was pronounced near the picking-ripe stage. Only fructose $(1.72 \mathrm{mM})$ and glucose $(0.72$ $\mathrm{mM}$ ) were detected in nectarine pollen exudates (data not included).
Growth of $B$. cinerea in media amended with sugar. Sugar concentrations used were nonlinear. Transmittance was therefore plotted against the $\log _{10}$ transformation values (Fig. 1). Absorbance readings indicated that the hexose sugars fructose and glucose, and sucrose, did not markedly influence the growth of $B$. cinerea at concentrations below 0.22 and 0.12 $\mathrm{mM}$, respectively. The hexose sugars caused a steady increase in growth when supplied at concentrations in excess of 0.44
$\mathrm{mM}$, and sucrose caused the same steady increase at $0.23 \mathrm{mM}$. The stimulatory effect was most pronounced for fructose and sucrose. Sorbitol, on the other hand, supported fungal growth only when supplied at concentrations in excess of $0.66 \mathrm{mM}$.

$B$. cinerea utilized fructose and glucose at a more or less equal rate from growth media amended with sugar at levels corresponding with concentrations found in exudates of immature fruit (Fig. 2). Sucrose was rapidly taken up and was almost

Table 2. Germination and growth of Botrytis cinerea conidia after $8 \mathrm{~h}$ at $21^{\circ} \mathrm{C}$ on raised slides in exudates ${ }^{\mathrm{v}}$ of Harry Pickstone plum fruit obtained at different developmental stages during three growing seasons

\begin{tabular}{|c|c|c|c|c|c|c|c|c|c|c|c|c|}
\hline \multirow{3}{*}{$\begin{array}{l}\text { Weeks before } \\
\text { harvest }\end{array}$} & \multicolumn{6}{|c|}{ Germination (\%) } & \multicolumn{6}{|c|}{ Germ tube length $(\mu \mathrm{m})$} \\
\hline & \multicolumn{2}{|c|}{ Year 1} & \multicolumn{2}{|c|}{ Year 2} & \multicolumn{2}{|c|}{ Year 3} & \multicolumn{2}{|c|}{ Year 1} & \multicolumn{2}{|c|}{ Year 2} & \multicolumn{2}{|c|}{ Year 3} \\
\hline & $\mathbf{W}^{\mathbf{w}}$ & $\mathbf{E}^{\mathbf{x}}$ & $\mathbf{W}$ & $\mathbf{E}$ & $\mathbf{W}$ & $\mathbf{E}$ & $\mathbf{W}$ & $\mathbf{E}$ & $\mathbf{W}$ & $\mathbf{E}$ & $\mathbf{W}$ & $\mathbf{E}$ \\
\hline \multirow[t]{2}{*}{14} & 71.0 & 65.5 & $\ldots{ }^{y}$ & $\ldots$ & 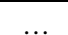 & . & 9.1 & 10.9 & $\ldots$ & $\ldots$ & . & \\
\hline & 69.2 & 70.0 & \multirow{3}{*}{80.8} & & 79.0 & 74.6 & 8.1 & 8.3 & . & & 13.4 & 13.5 \\
\hline 11 & & & & \multirow[t]{2}{*}{82.0} & & & & & \multirow[t]{2}{*}{$\dddot{16.2}$} & \multirow[t]{2}{*}{$19.2 * z$} & & \\
\hline 10 & 69.2 & 71.3 & & & 73.7 & 79.9 & 10.0 & 9.5 & & & 13.7 & 16.7 \\
\hline 9 & $\ldots$ & $\ldots$ & 78.5 & 76.9 & $\ldots$ & $\ldots$ & $\ldots$ & $\ldots$ & \multirow[t]{2}{*}{13.8} & \multirow{2}{*}{$17.5^{*}$} & $\ldots$ & $\ldots$ \\
\hline 8 & 76.2 & 76.3 & $\ldots$ & $\ldots$ & 73.2 & $68.3^{*}$ & 9.3 & 10.3 & & & 15.1 & 14.4 \\
\hline 7 & $\ldots$ & $\ldots$ & 79.4 & 78.1 & $\ldots$ & $\ldots$ & $\ldots$ & $\ldots$ & \multirow{2}{*}{15.3} & \multirow{2}{*}{$18.4^{*}$} & $\ldots$ & $\ldots$ \\
\hline 6 & 78.9 & 75.1 & $\ldots$ & $\ldots$ & 71.0 & 78.1 & 9.0 & 9.4 & & & 15.4 & $19.6^{*}$ \\
\hline 4 & 69.9 & $78.7 *$ & & & & & 7.7 & $10.5^{*}$ & & & & \\
\hline 3 & & $\ldots$ & 79.4 & $86.8 *$ & 76.6 & $86.4^{*}$ & $\ldots$ & $\ldots$ & 15.4 & $17.8^{*}$ & 14.5 & $22.7 *$ \\
\hline 2 & 80.3 & $88.1^{*}$ & 78.0 & $91.4 *$ & 77.8 & 81.7 & 7.5 & $11.6^{*}$ & 12.4 & $19.9^{*}$ & 15.3 & $19.1 *$ \\
\hline 1 & $\ldots$ & $\ldots$ & 77.8 & $85.3 *$ & $\ldots$ & $\ldots$ & $\ldots$ & $\ldots$ & 15.6 & $20.7 *$ & $\ldots$ & $\ldots$ \\
\hline 0 & 69.0 & $77.0^{*}$ & 78.0 & $87.9^{*}$ & 75.3 & $84.9^{*}$ & 8.4 & $10.5^{*}$ & 12.2 & $19.1 *$ & 16.0 & $27.0^{*}$ \\
\hline
\end{tabular}

${ }^{v}$ Exudates were collected from detached, unwashed fruit kept for $15 \mathrm{~h}$ at $20^{\circ} \mathrm{C}$ in moist chambers.

${ }^{\mathrm{w}}$ Spores incubated in sterile distilled water.

${ }^{x}$ Spores incubated in fruit exudates.

${ }^{\mathrm{y}}$ Not tested.

${ }^{\mathrm{z}}$ Numbers between columns differ significantly $(P=0.05)$ according to Student's $t$ test.
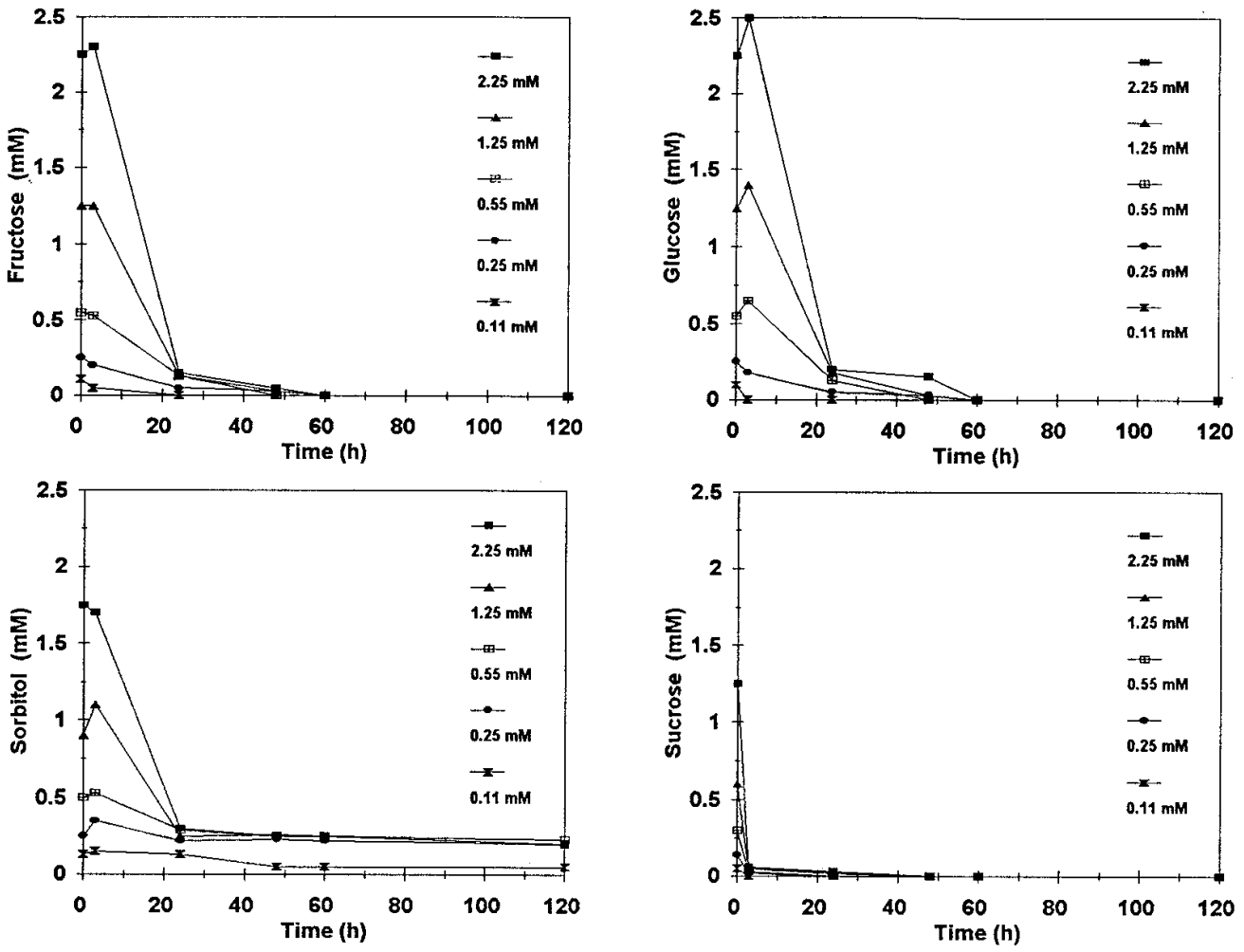

Fig. 3. Uptake of different sugars by Botrytis cinerea from a basic salts medium amended with sugar at levels (Table 1) corresponding to concentrations found in exudates of mature plum and nectarine fruit. 
completely utilized after $24 \mathrm{~h}$. Sorbitol, on the other hand, was not used by the fungus. Essentially the same trend in sugar utilization (Fig. 3) was found in media amended with sugar at the higher levels found in exudates of mature fruit. However, sorbitol, at concentrations in excess of 1.64 $\mathrm{mM}$, was taken up at a similar rate as was glucose during the initial $24 \mathrm{~h}$ of incubation, after which no further utilization occurred.

Effect of fruit and pollen exudates on conidium development. Conidium development in fruit exudates followed a similar trend during the three seasons (Table 2). Plum exudates usually had no effect on germination and germ tube growth prior to the pit-hardening stage, which occurred approximately 11 to 13 weeks before harvest. However, exudates significantly stimulated both phases of fungal development after the pit-hardening stage. This stimulatory effect on germ tube growth occurred earlier during year 2 .

Conidia developed differently in nectarine exudates (Table 3) from those in plum exudates. Both phases of conidium development were usually significantly inhibited by nectarine exudates prior to the period of rapid cell enlargement, which occurred approximately 2 weeks before harvest. During the period thereafter, nectarine exudates had no effect on germination rate, but stimulated germ tube growth significantly.

Pollen exudates stimulated germination and germ tube growth of $B$. cinerea conidia significantly (Table 4). Germination in plum and wild radish pollen exudates was significantly higher than in exudates from nectarine and yellow sorrel pollen. Germ tube growth, on the other hand, increased significantly in all pollen exudates.

Effect of pollen exudates on fruit decay. Exudate from yellow sorrel pollen increased the aggressiveness of $B$. cinerea on both fruit types significantly when added to conidia during the last 4 weeks prior to the picking-ripe stage (Table 5). Increases in the incidence of decay on nectarine fruit were the greatest, especially near the picking-ripe stage.

\section{DISCUSSION}

Unwounded nectarine and plum fruit are resistant to infection by $B$. cinerea during the early season but susceptible after cell enlargement $(14,16)$. These data indicate that changes in the composition of nectarine and plum fruit exudates over time may contribute to the late-season susceptibility. The sugar composition of the exudate of both fruit types increased significantly during the period of pit hardening and rapid cell enlargement. The stimulatory effect of fruit exudates on growth of $B$. cinerea on the raised slides synchronized with the period of rapid sugar release from the fruit and the shift in susceptibility.

Prior to pit hardening, only glucose, fructose, and sorbitol occurred in the fruit exudates, whereas sucrose appeared during the period of rapid cell enlargement. The reducing sugars and sorbitol leached at relatively low rates from both fruit types prior to pit hardening. At corresponding concentrations, they did not influence fungal growth in the mineral medium. Fungal growth was only enhanced when either of the reducing sugars or sucrose was supplied in excess of 0.27 and $0.14 \mathrm{mM}$, respectively, or when sorbitol was supplied in excess of $0.66 \mathrm{mM}$. During the last 2 weeks prior to harvest, total sugar in plum exudates was near these values, whereas in nectarine exudates it was far in excess of these values. Glucose, fructose, and sucrose were found to favor infection of broad bean leaves by $B$. cinerea, but sorbitol did not (18). Other researchers $(8,9,19)$ reported that the stimulation of $B$. cinerea conidia by grape berry exudates increased in the last month of ripening, which corresponds with the period of susceptibility, in which a large increase in sugar content of the exudates occurs (22).

Our results on the growth rate and utilization of simple sugars by $B$. cinerea from the growth medium, and on the virulence of the pathogen, support the findings of
Brodie and Blakeman $(3,4)$ and Edlich et al. (10). According to Brodie and Blakeman (4), sucrose is taken up more readily by $B$. cinerea conidia than is glucose, whereas the aggressiveness of the fungus is enhanced more by glucose than by fructose (10). Sucrose is hydrolyzed by fungal invertases to these hexose sugars (27). The availability of increasing amounts of sucrose on ripening fruits may thus favor growth of $B$. cinerea, both in saprophytic and parasitic modes, as was suggested by Edlich et al. (10).

Prior to the period of rapid cell enlargement, growth of $B$. cinerea on raised slides was inhibited by nectarine exudates. This might have been due to the presence of inhibitory substances in the fruit exudates. Pezet and Pont $(23,24)$ and Padgett and Morrison (22) demonstrated that immature grape berries exude onto their surface substances inhibitory to $B$. cinerea. The inhibitory effect of these substances decreased later in the season. A similar situation may occur on nectarine. However, the sharp increase in the amount of sugars in nectarine exudates during the last week before harvest may also contribute to the shift in inhibition. Mansfield and Deverall (20) showed that the addition of sugars enabled $B$. cinerea to overcome the inhibitory action of wyerone acid, an impor-

Table 4. Germination and growth of Botrytis cinerea conidia after $8 \mathrm{~h}$ at $21^{\circ} \mathrm{C}$ on raised slides in pollen exudate

\begin{tabular}{lcc}
\hline Pollen source & $\begin{array}{c}\text { Germination } \\
(\boldsymbol{\%})\end{array}$ & $\begin{array}{c}\text { Germ tube } \\
\text { length }(\boldsymbol{\mu m})\end{array}$ \\
\hline Nectarine & $62.6 \mathrm{~b}^{\mathrm{w}}$ & $31.6 \mathrm{a}$ \\
Plum & $79.3 \mathrm{a}$ & $32.0 \mathrm{a}$ \\
Wild radish $^{\mathrm{x}}$ & $86.8 \mathrm{a}$ & $36.0 \mathrm{a}$ \\
Yellow sorrel $^{\mathrm{y}}$ & $63.3 \mathrm{~b}$ & $33.4 \mathrm{a}$ \\
Control $^{\mathrm{z}}$ & $38.5 \mathrm{c}$ & $20.0 \mathrm{~b}$ \\
\hline
\end{tabular}

${ }^{w}$ Numbers in columns followed by the same letter do not differ significantly $(P=0.05)$ according to Duncan's multiple range test.

${ }^{x}$ Wild radish $=$ Raphanus raphanistrum.

y Yellow sorrel $=$ Oxalis pes-caprae .

${ }^{\mathrm{z}}$ Spores suspended in sterile distilled water.

Table 3. Germination and growth of Botrytis cinerea conidia after $8 \mathrm{~h}$ at $21^{\circ} \mathrm{C}$ on raised slides in exudates ${ }^{\mathrm{v}}$ of Sunlite nectarine fruit obtained at different developmental stages during three different growing seasons

\begin{tabular}{|c|c|c|c|c|c|c|c|c|c|c|c|c|}
\hline \multirow{3}{*}{$\begin{array}{l}\text { Weeks before } \\
\text { harvest }\end{array}$} & \multicolumn{6}{|c|}{ Germination (\%) } & \multicolumn{6}{|c|}{ Germ tube length $(\mu \mathrm{m})$} \\
\hline & \multicolumn{2}{|c|}{ Year 1} & \multicolumn{2}{|c|}{ Year 2} & \multicolumn{2}{|c|}{ Year 3} & \multicolumn{2}{|c|}{ Year 1} & \multicolumn{2}{|c|}{ Year 2} & \multicolumn{2}{|c|}{ Year 3} \\
\hline & $\mathbf{W}^{\mathbf{w}}$ & $\mathbf{E}^{\mathbf{x}}$ & $\mathbf{W}$ & $\mathbf{E}$ & $\mathbf{W}$ & $\mathbf{E}$ & $\mathbf{W}$ & $\mathbf{E}$ & $\mathbf{W}$ & $\mathbf{E}$ & $\mathbf{W}$ & $\mathbf{E}$ \\
\hline 9 & 82.3 & $52.6^{* \mathrm{y}}$ & 76.6 & $54.1 *$ & 66.2 & $50.6^{*}$ & 15.0 & $10.9^{*}$ & 13.7 & 12.7 & 13.9 & $8.5^{*}$ \\
\hline 7 & $\ldots^{z}$ & $\ldots$ & 75.6 & 72.4 & 73.3 & $17.6^{*}$ & $\ldots$ & $\ldots$ & 14.5 & 14.2 & 12.8 & $7.5^{*}$ \\
\hline 5 & 72.2 & 66.9 & 73.3 & $66.3 *$ & $\ldots$ & $\ldots$ & 11.7 & 12.5 & 13.3 & 11.7 & $\ldots$ & $\ldots$ \\
\hline 4 & & & & & 77.0 & $21.3^{*}$ & & & & & 13.1 & $8.6^{*}$ \\
\hline 3 & 74.0 & $60.8^{*}$ & 72.8 & $61.0^{*}$ & & & 13.0 & 15.7 & 11.5 & $15.5^{*}$ & & \\
\hline 2 & & & & & 68.5 & $39.1^{*}$ & & $\ldots$ & & & 15.5 & $10.9^{*}$ \\
\hline 1 & 76.4 & 82.8 & 76.3 & 83.9 & 76.7 & 79.7 & 14.9 & $24.7^{*}$ & 15.6 & $23.1^{*}$ & 16.1 & 18.1 \\
\hline 0 & 83.4 & 83.2 & 80.9 & 84.2 & 71.5 & 77.8 & 13.6 & $25.1 *$ & 13.1 & $23.4 *$ & 15.7 & 16.8 \\
\hline
\end{tabular}

${ }^{\mathrm{v}}$ Exudates were collected from detached, unwashed fruit kept for $15 \mathrm{~h}$ at $20^{\circ} \mathrm{C}$ in moist chambers.

${ }^{\mathrm{w}}$ Spores incubated in sterile distilled water.

${ }^{x}$ Spores incubated in fruit exudates.

$\mathrm{y} *$ Numbers between columns differ significantly $(P=0.05)$ according to Student's $t$ test.

$\mathrm{z} \ldots=$ not tested. 
Table 5. Percent Harry Pickstone plum and Sunlite nectarine fruit ${ }^{\mathrm{w}}$ showing Botrytis cinerea postharvest decay after inoculation at different developmental stages with conidia suspended in pollen exudate

\begin{tabular}{|c|c|c|c|c|}
\hline \multirow{3}{*}{$\begin{array}{l}\text { Weeks before } \\
\text { harvest }\end{array}$} & \multicolumn{4}{|c|}{ Decay fruit $(\%)$} \\
\hline & \multicolumn{2}{|c|}{ Plum } & \multicolumn{2}{|c|}{ Nectarine } \\
\hline & $\mathbf{W}^{\mathbf{x}}$ & $\mathbf{E}^{\mathbf{y}}$ & $\mathbf{W}$ & $\mathbf{E}$ \\
\hline 10 & $0 \mathrm{e}^{\mathrm{z}}$ & $0 \mathrm{e}$ & $0 \mathrm{~g}$ & $0 \mathrm{~g}$ \\
\hline 6 & $0 \mathrm{e}$ & $0 \mathrm{e}$ & $5 \mathrm{fg}$ & $5 \mathrm{fg}$ \\
\hline 4 & $0 \mathrm{e}$ & $5 \mathrm{~d}$ & $10 \mathrm{f}$ & $24.7 \mathrm{e}$ \\
\hline 2 & $0 \mathrm{e}$ & $20 \mathrm{c}$ & $5.3 \mathrm{f}$ & $90 \mathrm{ab}$ \\
\hline 1 & $0 \mathrm{e}$ & $30.3 \mathrm{~b}$ & $40 \mathrm{~d}$ & $90.7 \mathrm{a}$ \\
\hline 0 & $20 \mathrm{c}$ & $40.3 \mathrm{a}$ & $80 \mathrm{c}$ & $85 \mathrm{bc}$ \\
\hline
\end{tabular}

${ }^{\mathrm{w}}$ Fruit were kept after inoculation for 7 days at $22^{\circ} \mathrm{C}$ in moist chambers at high humidity $(\geq 93 \%)$.

${ }^{\mathrm{x}}$ Spores suspended in sterile distilled water.

${ }^{\mathrm{y}}$ Spores suspended in pollen exudate of yellow sorrel.

${ }^{\mathrm{z}}$ Numbers in columns and rows followed by the same letter do not differ significantly $(P=0.05)$ according to the least significant difference test.

tant phytoalexin produced by Vicia faba. The large quantity of sugar can also enable $B$. cinerea to overcome its inability to penetrate immediately by increasing the amount of superficial growth $(7,28)$. This increased the probability that hyphae would randomly encounter the usual sites of penetration of plum and nectarine fruit (16). Superficial growth was noted at the inoculation site on sound picking-ripe plum and nectarine fruit (16).

The importance of pollen in supplying additional sugar to those in the exudates is probably underestimated in the infection of stone fruit by $B$. cinerea. Locally, different types and cultivars of stone fruit with different blossoming periods are cultivated in nearby orchards. Other plants, including weeds, may contribute to a continuous presence of pollen on fruit. A wide range of pollen has been reported to stimulate the germination and growth of germ tubes of $B$. cinerea markedly, as well as increasing infection of petals (2). Aggressiveness of $B$. cinerea on fruit was enhanced by pollen exudates in these experiments. Stone fruit and weed pollen with a high content of reducing sugars are likely to lead to a similar stimulation on fruit in the orchard.

\section{LITERATURE CITED}

1. Blakeman, J. P. 1975. Germination of Botrytis cinerea conidia in vitro in relation to nutrient conditions on leaf surfaces. Trans. Br. Mycol. Soc. 65:239-247.

2. Blakeman, J. P. 1980. Behaviour of conidia on aerial plant surfaces. Pages 126-151 in: The Biology of Botrytis. J. R. Coley-Smith,
K. Verhoeff, and W. R. Jarvis, eds. Academic Press, New York.

3. Brodie, I. D. S., and Blakeman, J. P. 1975. Competition for carbon compounds by a leaf surface bacterium and conidia of Botrytis cinerea. Physiol. Plant Pathol. 6:125-135.

4. Brodie, I. D. S., and Blakeman, J. P. 1976. Competition for exogenous substrates in vitro by leaf surface micro-organisms and germination of conidia of Botrytis cinerea. Physiol. Plant Pathol. 9:227-239.

5. Brown, W. 1922. Studies in the physiology of parasitism. VIII. On the exosmosis of nutrient substances from the host tissue into the infection drop. Ann. Bot. 36:101-119.

6. Chou, C. M., and Preece, T. F. 1968. The effect of pollen grains on infections caused by Botrytis cinerea Fr. Ann. Appl. Biol. 62:1122.

7. Clark, C. A., and Lorbeer, J. W. 1977. The role of phyllosphere bacteria in pathogenesis of Botrytis cinerea and B. squamosa on onion leaves. Phytopathology 67:96-100.

8. Doneche, B. 1986. The nature of exudates of grapes berries and their effect on germination of Botrytis cinerea. Agronomie 6:67-74.

9. Doneche, B., and Pucheu-Planté, B. 1986. Influence de devers effecteurs sur le développement de Botrytis cinerea en milieu synthétique. Vitis 25:21-30.

10. Edlich, W., Lorenz, G., Lyr, H., Nega, E., and Pommer, E.-H. 1989. New aspects on the infection mechanism of Botrytis cinerea Pers. Neth. J. Plant Pathol. 95(Suppl. 1):53-62.

11. Fourie, J. F. 1992. Postharvest decay of stone fruit: infection and latency of Botrytis cinerea. Ph.D. (Agric.) diss. University of Stellenbosch, Stellenbosch, South Africa.

12. Fourie, J. F., and Holz, G. 1985. Postharvest fungal decay of stone fruit in the South-Western Cape. Phytophylactica 17:175-177.

13. Fourie, J. F., and Holz, G. 1985. Artificial inoculation of stone fruit with Botrytis cinerea, Monilinia laxa and Rhizopus stolonifer.
Phytophylactica 17:179-181.

14. Fourie, J. F., and Holz, G. 1987. Infection and decay of stone fruit by Botrytis cinerea and Monilinia laxa at different stages after anthesis. Phytophylactica 19:45-46.

15. Fourie, J. F., and Holz, G. 1994. Infection of plum and nectarine flowers by Botrytis cinerea. Plant Pathol. 43:309-315.

16. Fourie, J. F., and Holz, G. 1995. Initial infection processes by Botrytis cinerea on nectarine and plum fruit and the development of decay. Phytopathology 85:82-87.

17. Fourie, P. C., and Basson, D. S. 1990. Sugar content of almond, pecan, and macadamia nuts. J. Agric. Food Chem. 38:101-104.

18. Harper, A. M., Strange, R. N., and Langcake, P. 1981. Characterization of the nutrient required by Botrytis cinerea to infect broad bean leaves. Physiol. Plant Pathol. 19:153167.

19. Kosuge, T., and Hewitt, W. M. B. 1964. Exudates of grape berries and their effect on germination of conidia of Botrytis cinerea. Phytopathology 54:167-172.

20. Mansfield, J. W., and Deverall, B. J. 1974. The rates of fungal development and lesion formation in leaves of Vicia faba during infection by Botrytis cinerea and Botrytis fabae. Ann. Appl. Biol. 76:77-89.

21. Orellana, R. G., and Thomas, C. A. 1962 Nature of predisposition of castorbeans to Botrytis. I. Relation of leachable sugar and certain other biochemical constituents of the capsule to varietal susceptibility. Phytopathology 52:533-538.

22. Padgett, M., and Morrison, J. C. 1990 Changes in grape berry exudates during fruit development and their effect on mycelial growth of Botrytis cinerea. J. Am. Soc. Hortic. Sci. 115:269-273.

23. Pezet, R., and Pont, V. 1984. Botrytis cinerea: Activité antifongique dans les jeunes grappes de Vitis vinefera, varieté Gamay. Phytopathol. Z. 111:73-81.

24. Pezet, R., and Pont, V. 1984. Activité antifongique dans les baies de Vitis vinefera: effets d'acides origaniques et du ptérostilbène. Rev. S. Vit. Arbor. Hortic. 20:303-309.

25. Schlagbauer, H. E., and Holz, G. 1990. Infection and colonization of plum blossoms by Monilinia laxa. Phytophylactica 22:419-422.

26. Van Den Heuvel, J. 1987. Substances in dead plant tissue that stimulate infection of French bean leaves by Botrytis cinerea. Neth. J. Plant Pathol. 93:135-146.

27. Whipps, J. M., and Lewis, D. H. 1981. Patterns of translocation, storage and interconversion of carbohydrates. Pages 47-83 in: Effects of Disease on the Physiology of the Growing Plant. P. G. Ayres, ed. Cambridge University, London.

28. Wildman, H. G., and Parkinson, D. 1981 Comparison of germination of Cladosporium herbarum and Botrytis cinerea conidia in vitro in relation to nutrient conditions on leaf surfaces. Can. J. Bot. 59:854-861. 